\title{
Oxidative stress induces p21 expression in pancreatic islet cells: possible implication in beta-cell dysfunction
}

\author{
H. Kaneto, Y. Kajimoto, Y. Fujitani, T. Matsuoka, K. Sakamoto, M. Matsuhisa, Y. Yamasaki, and M. Hori \\ Department of Internal Medicine and Therapeutics, Osaka University Graduate School of Medicine, Japan
}

\section{Abstract}

Aims/hypothesis. Prolonged poor glycaemic control in patients with Type II (non-insulin-dependent) diabetes mellitus often causes pancreatic beta-cell dysfunction accompanied by decreases in insulin biosynthesis and beta-cell proliferation. This is well known as a clinical concept called glucose toxicity. Whereas oxidative stress is provoked under diabetic conditions, we examined the possible implication of cyclin-dependent kinase (Cdk) inhibitor p21 (WAF1/ CIP1/Sdi1) in beta-cell dysfunction mediated by oxidative stress.

Methods. Oxidative stress was induced in isolated rat pancreatic islet cells by treatment with $\mathrm{H}_{2} \mathrm{O}_{2}$ and mRNA expression of p21 and insulin was examined by northern blot analyses. Also, the expression of p21 and insulin mRNA was examined in Zucker diabetic fatty rat. In islet cells p21 was overexpressed using adenovirus and its effect on insulin gene transcription was examined.
Results. When oxidative stress was charged on isolated rat pancreatic islet cells, p21 mRNA expression was induced whereas insulin mRNA was decreased. Also, when diabetes developed in Zucker diabetic fatty rats, p21 expression was induced and the insulin mRNA expression was reduced. As support for the implication of p21 in impairment of beta-cell function, the p21 overexpression in the islet cells suppressed the insulin gene transcription.

Conclusions/interpretation. The expression of cyclindependent kinase inhibitor $\mathrm{p} 21$, which can be induced by oxidative stress, increases in pancreatic islet cells upon development of diabetes. By suppressing cell proliferation and insulin biosynthesis, the p21 induction is likely to be implicated in the beta-cell glucose toxicity. [Diabetologia (1999) 42: 1093-1097\}

Keywords Oxidative stress, glucose toxicity, p21, cyclin-dependent kinase, insulin gene, insulin secretion, beta-cell.
The maintenance of normal pancreatic beta-cell function requires regulation of the rate of insulin biosynthesis and beta-cell number $[1,2]$. Any defects in these regulations can lead to Type II (non-insulin-de-

Received: 29 March 1999 and in revised form: 21 May 1999

Corresponding author: Dr. Y. Kajimoto, Department of Internal Medicine and Therapeutics, Osaka University Graduate School of Medicine, 2-2, Yamadaoka, Suita City, Osaka Pref. 565-0871, Japan

Abbreviations: ROS, Reactive oxygen species; Cdk, cyclin-dependent kinase; SD rat, Sprague-Dawley rat; ZDF rat, Zucker diabetic fatty rat; ZLC rat, Zucker lean control rat; HBSS, Hanks' balanced salt solution. pendent) diabetes mellitus, as suggested by the association between the development of diabetes and the substantial reduction of insulin content in pancreatic islet cells of Zucker diabetic fatty (ZDF) rats [3]. Lines of evidence have shown that the toxic effect of prolonged poor glycaemic control on beta cells, called glucose toxicity, has a key role in the progression of beta-cell dysfunction $[4,5]$. According to in vitro studies using HIT-T15 and betaTC-6 derived from beta cells [6-9], long-term exposure to a high glucose concentration causes the cells to suppress insulin gene transcription and reduces their capacity for insulin secretion. Some transcription factors for the insulin gene were found to be impaired under 
high glucose conditions [5, $8-10]$, however, the overall mechanism underlying the reduction in insulin biosynthesis is not known.

To obtain a clue to understanding the molecular basis of beta-cell dysfunction in diabetes, this study focused on the association between oxidative stress and the induction of $\mathrm{p} 21$. With long-term high glucose concentrations, the production of various reducing sugars increases as a result of enhanced glycolysis and the polyol pathway which leads to an increase in reactive oxygen species (ROS) production through induction of the glycation reaction $[11,12]$. The beta cells, in which advanced glycation end products formation can be detected with high glucose concentrations [13], cannot be excluded from this phenomenon. Once oxidative stress is imposed on beta cells under diabetic conditions, it is likely to cause profound damage to these cells due to low antioxidant enzyme expression [14]. As support for the possible implication of ROS in the glucose toxicity, we recently showed that ROS production mediated by glycation reduces insulin gene transcription [15] and also decreases the number of beta cells through apoptosis [16].

p21 also known as WAF1 (wild-type p53-activated fragment 1) [17], Cip1 (Cdk-interacting protein 1) [18], or Sdi1 (senescent cell-derived inhibitor 1) [19], is a key regulator of the cell cycle. It inhibits cyclindependent kinase (Cdk) [20]; an increase in p21 level relative to $\mathrm{Cdk}$ converts active $\mathrm{Cdk}$ complexes into inactive ones and thus prevents the cells from entering the $\mathrm{S}$ phase of the cell cycle. Among the family of Cdk inhibitors, p21 is known to be widely expressed in various tissues and cells and has a critical role in maintaining morphological and functional homeostasis $[21,22]$. Because p21 expression is known to be activated in some cells when they are exposed to oxidative stress $[23,24]$, it could be similarly upregulated under diabetic conditions and play a part in glucose toxicity. Here we show that oxidative stress triggers p21 induction in pancreatic islet cells and this leads to suppression of insulin gene expression in the cells. As support for the possible pathophysiological relevance of this phenomenon, we found that p21 expression was induced in islet cells of Zucker diabetic fatty rats. Thus we propose that $\mathrm{p} 21$ is a molecule which mediates in part the suppression of betacell proliferation and insulin biosynthesis as seen in diabetes.

\section{Materials and methods}

Animals. Sprague-Dawley (SD) male rats were purchased from Clea Japan, Tokyo, Japan, and Zucker diabetic fatty (ZDF) and Zucker lean control (ZLC) male rats were purchased from Genetic Models, Indianapolis, Ind., USA. Blood glucose concentration was measured by the glucose oxidase method using a glucose analyser (MS-GR101; Terumo, Tokyo, Japan). The animal studies were conducted in accordance with the "Principles of laboratory animal care" in NIH publication no. 85-23.

Isolation of rat pancreatic islet cells. Islet cells were isolated from SD, ZDF, and ZLC rats by collagenase digestion and Ficoll gradient. Under ether anaesthesia, the common bile duct was clamped at its entrance to the duodenum and cannulated with a 23-gauge needle. Approximately $15 \mathrm{ml}$ of cold Hanks' balanced salt solution (HBSS) containing $1 \mathrm{mg} / \mathrm{ml}$ collagenase was injected into the common bile duct. The distended pancreas was removed and incubated for $20 \mathrm{~min}$ at $37^{\circ} \mathrm{C}$. Cold HBSS was added to stop the digestion and the digested pancreas was dispersed into small fragments by pipetting. The tube was then centrifuged at $1000 \mathrm{rpm}(120 \mathrm{~g})$ for $1 \mathrm{~min}$. The supernatant was discarded and the pellet was washed twice with cold HBSS. The tissue suspension was passed through a mesh filter to remove the large undigested tissues. The filtered tissue was washed again and the pellet was resuspended in $25 \%$ Ficoll solution. The tissue suspension was layered under a discontinuous Ficoll gradient $(23,20.5$, and $11 \%$ ) followed by centrifugation at $800 \mathrm{rpm}(70 \mathrm{~g})$ for $3 \mathrm{~min}$ and at $2200 \mathrm{rpm}(500 \mathrm{~g})$ for $7 \mathrm{~min}$. The tissue at the 20.5/11 interface was collected and washed twice with cold HBSS. The islets were cultured overnight in RPMI medium supplemented with $10 \%$ fetal calf serum, 100 units $/ \mathrm{ml}$ penicillin, and $0.1 \mathrm{mg} / \mathrm{ml}$ streptomycin sulphate in a humidified atmosphere of $5 \% \mathrm{CO} 2$ at $37^{\circ} \mathrm{C}$ and used for experiments.

Preparation of recombinant adenovirus containing the cDNA encoding p21. A recombinant adenovirus containing the cDNA encoding p21 was prepared using an adenovirus expression vector kit (Takara Biochemicals, Osaka, Japan). Following the manufacturer's directions, p21 cDNA sequences were inserted into the cosmid vector pAxCAwt containing CAG promoter and then the vector was transfected into 293 cells. The resultant recombinant adenovirus (Ade-p21) was amplified in the same cells. Control adenovirus (Ade- $\beta$ gal) was also obtained using the cosmid vector containing the $\beta$-galactosidase cDNA sequences. Infection of adenovirus was achieved by culturing the cells with the virus for $60 \mathrm{~min}$.

Northern blot analyses. Total RNA was isolated from rat pancreatic islet cells which had been cultured for various times in the presence of appropriate reagents and northern blot analyses were done. One microgram of total RNA was size-fractionated and transferred onto a Hybond- $\mathrm{N}^{+}$membrane (Amersham Japan, Tokyo, Japan). After hybridization with a ${ }^{32} \mathrm{P}-\mathrm{la}-$ belled p 21 or insulin cDNA probe at $42^{\circ} \mathrm{C}$ in the presence of $50 \%$ formamide, the membrane was washed twice with $1 \times$ SSPE $(180 \mathrm{mmol} \mathrm{NaCl}, 10 \mathrm{mmol}$ sodium phosphate, 1 mmol EDTA, pH 7.4) and $0.1 \%$ sodium dodecyl sulphate at $50^{\circ} \mathrm{C}$ for $15 \mathrm{~min}$. For evaluation of $\beta$-actin mRNA amounts, the same membranes were rehybridized with a ${ }^{32} \mathrm{P}$-labelled $\beta$ actin probe following the same procedure as described above. Kodak XAR film was exposed with an intensifying screen at $-80^{\circ} \mathrm{C}$.

Evaluation of glucose-induced insulin secretion. Insulin secretion induced by glucose was determined using the static incubation method [25]. Isolated rat pancreatic islet cells were pre-incubated for 30 min with HEPES-balanced Krebs-Ringer bicarbonate buffer and then incubated for $2 \mathrm{~h}$ in the same buffer supplemented with $0.5 \%$ BSA and the required concentration of glucose. The insulin secreted into the medium was determined using a Lebis Radioimmunoassay kit (Shibayagi, 
Gunma, Japan) using rat insulin as the standard.Total protein amounts in the extracts were measured using a protein assay (Bio-rad Laboratories, Richmond, Calif., USA) with the BSA standard. Data of insulin concentration were normalized for protein concentration.

\section{Results}

Induction of Cdk inhibitor p21 expression in rat pancreatic islet cells treated with ROS. Oxidative stress is known to be provoked by high glucose concentrations $[11,12]$ and is suggested to play a part in betacell dysfunction in diabetes $[15,16]$. To evaluate the possible involvement of $\mathrm{p} 21$ in beta-cell glucose toxicity, we first examined whether oxidative stress also induces p21 expression in pancreatic islet cells as seen in some other cell populations [23, 24]. Islet cells were isolated from non-diabetic SD rats and the effect of $\mathrm{H}_{2} \mathrm{O}_{2}$ was evaluated.

The results of northern blot analyses showed that the amount of p21 mRNA expressed in the islet cells was increased by treatment with $\mathrm{H}_{2} \mathrm{O}_{2}$ in a dose-dependent manner (Fig. 1A). Thus, oxidative stress appears to be a potent inducer of $\mathrm{p} 21$ expression in islet cells. On the other hand, treatment with $\mathrm{H}_{2} \mathrm{O}_{2}$ caused a dose-dependent decrease in insulin mRNA (Fig.1B), agreeing with a previous observation obtained with the beta-cell-derived cell line HIT [15].

Induction of p21 expression in hyperglycaemic ZDF rats. We next examined whether the p21 expression is also induced in vivo in diabetes. The animal models used were ZDF rats and control ZLC rats. The development of diabetes in ZDF rats has many features in common with human Type II diabetes, including progressive insulin resistance and insufficiency of beta-cell compensation leading to hyperglycaemia [3]. Blood glucose concentrations were $9.5 \pm$ $1.2 \mathrm{mmol} / \mathrm{l}$ at 6 weeks and $23.2 \pm 2.6 \mathrm{mmol} / \mathrm{l}$ at 12 weeks for the ZDF rats and $7.6 \pm 0.9 \mathrm{mmol} / \mathrm{l}$ at 6 weeks and $7.8 \pm 0.9 \mathrm{mmol} / \mathrm{l}$ at 12 weeks for the ZLC rats.

The results of northern blot analyses showed that p21 mRNA increases as hyperglycaemia becomes evident in ZDF rats: the p21 mRNA amount was 2.6fold higher at 12 weeks than at 6 weeks (Fig. 1C). No such increase in p21 mRNA was observed in the non-diabetic ZLC rats. Thus these observations indicated that $\mathrm{p} 21$ expression is indeed induced in $\mathrm{ZDF}$ rats and suggested that the increase was caused by the presence of hyperglycaemia. In contrast to the increase in p21 mRNA, insulin mRNA was decreased in ZDF rats at 12 weeks (Fig. 1C), as observed previously [3].

Insulin gene expression and glucose-induced insulin secretion in p21-overexpressed pancreatic islet cells. To evaluate the possible implication of $\mathrm{p} 21$ induction
A

B
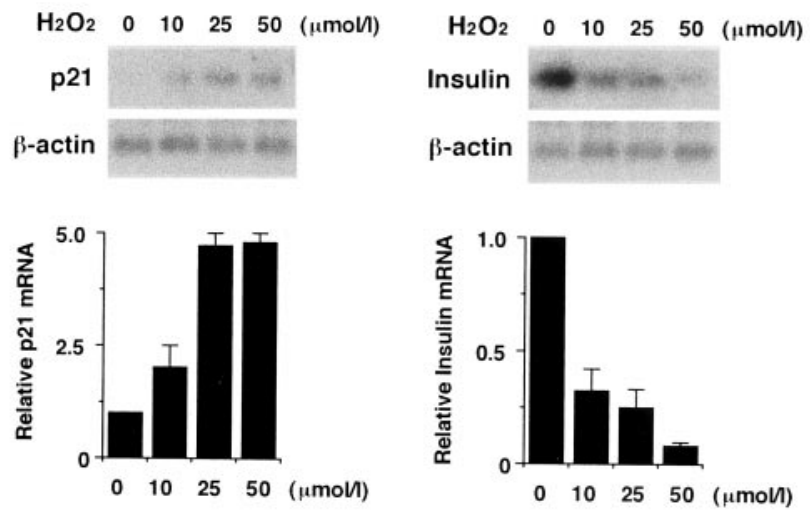

C

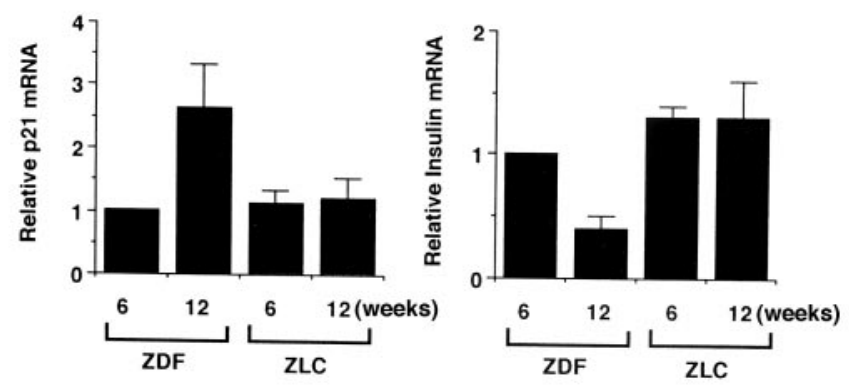

Fig. 1A-C. Evaluation of p 21 mRNA and insulin mRNA in pancreatic islets treated with $\operatorname{ROS}(\mathbf{A}, \mathrm{p} 21 ; \mathbf{B}$, insulin) and in islets of diabetic $\mathrm{ZDF}$ rats $(\mathbf{C})$. Isolated rat pancreatic islet cells were treated with 0 (vehicle only), 10, 25, or $50 \mu \mathrm{mol} / 1$ $\mathrm{H}_{2} \mathrm{O}_{2}$ for $24 \mathrm{~h}$ (for $\mathrm{p} 21$ ) or $48 \mathrm{~h}$ (for insulin) before isolation of total RNA used for northern blot analyses. Similar results were obtained in three independent experiments. For evaluation of p21 and insulin mRNA amount in ZDF and ZLC rats, pancreatic islet cells were isolated at 6 and 12 weeks of age and total RNA was obtained. Relative mRNA amounts of p21 and insulin were determined by densitometry and are expressed as means \pm SD in bar graphs with those of untreated islet cells (for $\mathbf{A}$ and $\mathbf{B}$ ) and of 6-week-old ZDF rats (for $\mathbf{C}$ ) being arbitrarily set at $1(n=3)$

in beta-cell dysfunction, we examined the effects of p21 on insulin gene expression and secretion. Using a recombinant adenovirus, p21 was exogenously overexpressed in islet cells isolated from non-diabetic $\mathrm{SD}$ rats.

Infection with the p21-expressing adenovirus (Ade-p21) led to an increase in p21 expression in the islet cells compared with uninfected cells or cells infected with a control adenovirus, Ade- $\beta$ gal (Fig. $2 \mathrm{~A}$, B). The amount of insulin mRNA was decreased by $60 \%$ in the p21-overexpressed islet cells whereas no decrease was observed in the Ade- $\beta$ gal-infected cells (Fig.2A, B). Thus the increase of p21 mRNA observed in islet cells from diabetic animals and in islet cells charged with oxidative stress may, in part, be responsible for the decrease in insulin mRNA observed in those cells. On the other hand, the p21 overexpres- 
A

B

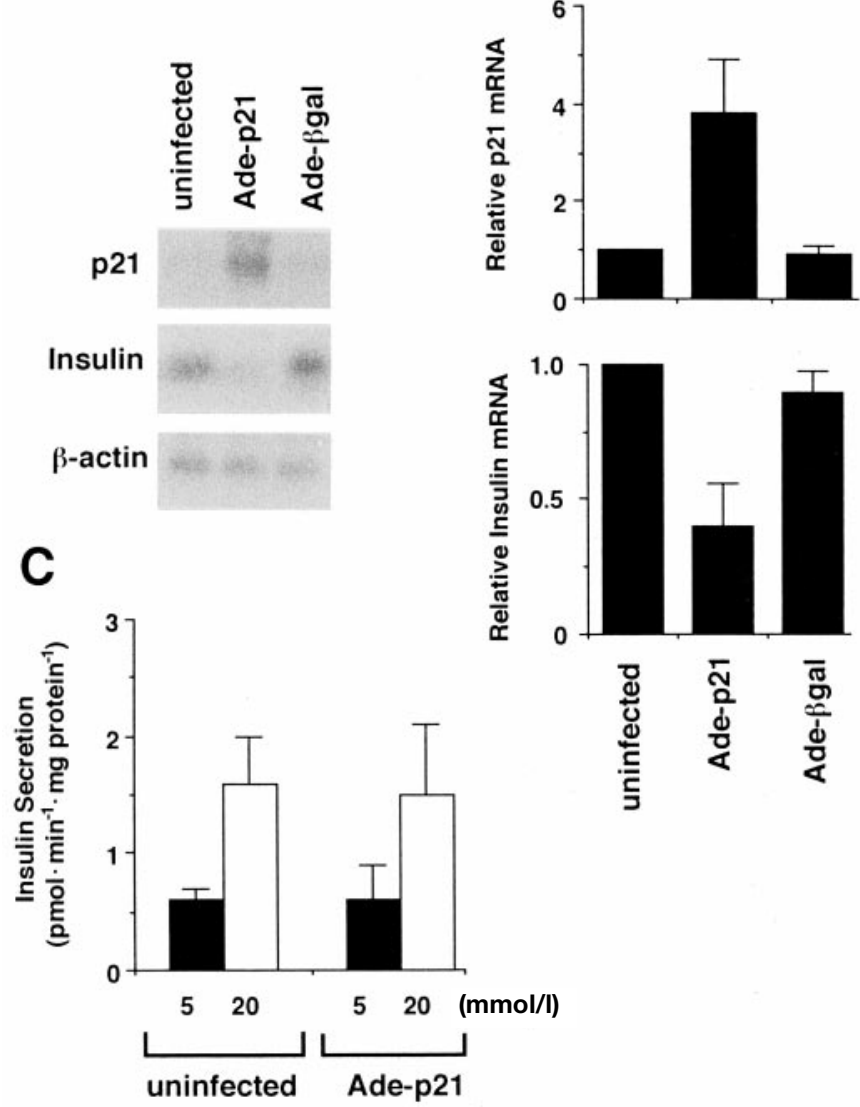

Fig. 2A-C. Effects of p21 overexpression on insulin mRNA amount $(\mathbf{A}, \mathbf{B})$ and insulin secretion induced by glucose $(\mathbf{C})$. Pancreatic islet cells were isolated from SD rats and were infected with a recombinant adenovirus, Ade-p21 or Ade- $\beta$ gal. At $48 \mathrm{~h}$ after the infection $(72 \mathrm{~h}$ after the isolation of islet cells), total RNA was isolated and used for northern blot analyses followed by densitometric analyses. Relative mRNA amounts of p21 and insulin are expressed as means \pm SD in bar graphs with those of uninfected islet cells being arbitrarily set at $1(n=3)$. Insulin secretion induced by glucose was examined in the uninfected islet cells and the cells infected with Ade-p21 72 hours after the infection $(96 \mathrm{~h}$ after the isolation of islet cells). The insulin secreted into the medium was examined as described in Materials and methods. Data are expressed as means \pm SD in bar graphs $(n=3)$

sion by adenovirus did not cause any appreciable change in the glucose-induced insulin secretion (Fig. 2C).

\section{Discussion}

In Type II diabetic patients, prolonged poor glycaemic control often leads to a decline in insulin secretion which is stimulated by glucose, accompanied by decreases in the insulin biosynthesis and beta-cell number $[1,2]$. For effective prevention and treatment of diabetes, it is essential to understand the molecular mechanism of this phenomenon. In this study, we have shown that oxidative stress, which is known to be provoked under hyperglycaemia, induces p21 expression in isolated rat pancreatic islet cells (Fig. 1A, B). Also we found that p21 expression is induced in islets of diabetic ZDF rats (Fig. 1C). Considering the function of p21 as a Cdk inhibitor [17-19], its induction is likely to cause the suppression of cell proliferation, although the limitation of islet cell preparation prevented reliable quantification of the cell proliferation rate. Since we previously found that ROS induce apoptosis in beta cells [16], ROS is possibly involved in reducing the number of beta cells by both increasing cell death and suppressing cell replication.

Apart from the possible effects on the cell cycle, p21 may also function as a potential inhibitor of insulin gene transcription; overexpression of p21 in isolated islet cells using a recombinant adenovirus suppressed the insulin gene expression (Fig.2A, B). There seems to have been a similar observation with the beta-cell-derived cell line INS-1, although not discussed by those authors [10]. Thus the induction of p21 and reduction of insulin gene transcription, which are simultaneously observed in islet cells of diabetic animals as well as in islet cells treated with $\mathrm{H}_{2} \mathrm{O}_{2}$, are possibly not coincidental; instead, there could be some intercausal relation between these two phenomena. Despite the decrease in insulin mRNA in p21-overexpressed islet cells, our study failed to show a decrease in insulin secretion stimulated by glucose; it was preserved at least until $72 \mathrm{~h}$ after the adenovirus infection (Fig.2C). The pathophysiological relevance of the decrease of insulin mRNA as a cause of impaired insulin secretion has, however, been suggested in the Type II diabetic model animals showing degranulation of beta cells [3]. Therefore, although limitations in experimental approach using cultured islet cells prevented us showing direct evidence, we assume that long-term suppression of insulin gene transcription would lead to the degranulation of beta cells and thereby suppress insulin secretion stimulated by glucose.

It remains to be clarified how the insulin mRNA is decreased by $\mathrm{p} 21$. Considering that suppression of the cell cycle in beta cells usually leads to an increase of insulin biosynthesis rather than a decrease [26], it is likely that suppression of the insulin gene transcription that is triggered by $\mathrm{p} 21$ is mediated through some other effects of $\mathrm{p} 21$ not correlated with the cell cycle. Not only does p21 bind and inhibit Cdks but it is also known to inactivate DNA polymerase, suggesting a broader function of p21 as a kinase inhibitor. As various intracellular signalling molecules such as protein kinase A seem to participate in insulin gene regulation, p21 might affect the function of such molecules and thereby negatively regulate insulin gene transcription independent of the cell cycle regulation. 
In conclusion, we propose $\mathrm{p} 21$ as a potential mediator of beta-cell glucose toxicity. Our results indicate that oxidative stress in beta cells induces p21 expression, which was shown to be induced in diabetic ZDF rats. Thus, p21 could be involved in beta-cell dysfunction in Type II diabetes by suppressing cell proliferation and insulin biosynthesis.

Acknowledgements. We thank Ms. N. Fujita for the excellent technical assistance. This work was supported in part by grants from Suzuken Memorial Foundation (to Y. Kajimoto) and a Grant-in-Aid for Scientific Research from the Ministry of Education of Japan (to Y. Kajimoto and Y. Yamasaki).

\section{References}

1. DeFronzo RA, Bonadonna RC, Ferrannini E (1992) Pathogenesis of NIDDM: a balanced overview. Diabetes Care 15: 318-368

2. Vinik A, Pittenger G, Rafaeloff R, Rosenberg L, Duguid W (1996) Determinants of pancreatic islet cell mass: a balance between neogenesis and senescence/apoptosis. Diabetes Review 4: 235-263

3. Tokuyama Y, Sturis J, DePaoli AM et al. (1995) Evolution of $\beta$-cell dysfunction in the male Zucker diabetic fatty rat. Diabetes 44: 1447-1457

4. Leahy JL, Bonner-Weir S, Weir GC (1992) Beta-cell dysfunction induced by chronic hyperglycemia: current ideas on the mechanism of the impaired glucose-induced insulin secretion. Diabetes Care 15: 442-455

5. Zangen DH, Bonner-Weir S, Lee CH et al. (1997) Reduced insulin, GLUT2, and IDX-1 in $\beta$-cells after partial pancreatectomy. Diabetes 46: 258-264

6. Robertson RP, Zhang H-J, Pyzdrowski KL, Walseth TF (1992) Preservation of insulin mRNA levels and insulin secretion in HIT cells by avoidance of chronic exposure to high glucose concentrations. J Clin Invest 90: 320-325

7. Robertson RP, Olson LK, Zhang H-J (1994) Differentiating glucose toxicity from glucose desensitization: a new message from the insulin gene. Diabetes 43: 1085-1089

8. Sharma A, Olson LK, Robertson RP, Stein R (1995) The reduction of insulin gene transcription in HIT-T15 $\beta$ cells chronically exposed to high glucose concentration is associated with loss of RIPE3b1 and STF-1 transcription factor expression. Mol Endocrinol 9: 1127-1134

9. Poitout V, Olson LK, Robertson RP (1996) Chronic exposure of $\beta$ TC- 6 cells to supraphysiologic concentrations of glucose decreases binding of the RIPE3b1 insulin gene transcription activator. J Clin Invest 97: 1041-1046

10. Olson LK, Qian J, Poitout V (1998) Glucose rapidly and reversibly decreases INS-1 cell insulin gene transcription via decrements in STF-1 and C1 activator transcription factor activity. Mol Endocrinol 12: 207-219

11. Sakurai T, Tsuchiya S (1998) Superoxide production from nonenzymatically glycation protein. FEBS Lett 236: 406-410
12. Hunt JV, Smith CC, Wolff SP (1991) Autoxidative glycosylation and possible involvement of peroxides and free radicals in LDL modification by glucose. Diabetes 39: $1420-1424$

13. Tajiri Y, Moller C, Grill V (1997) Long term effects of aminoguanidine on insulin release and biosynthesis: evidence that the formation of advanced glycosylation end products inhibits B cell function. Endocrinology 138: 273-280

14. Tiedge M, Lortz S, Drinkgern J, Lenzen S (1997) Relation between antioxidant enzyme gene expression and antioxidative defense status of insulin-producing cells. Diabetes 46: $1733-1742$

15. Matsuoka T, Kajimoto Y, Watada H et al. (1997) Glycation-dependent, reactive oxygen species-mediated suppression of the insulin gene promoter activity in HIT cells. J Clin Invest 99: 144-150

16. Kaneto H, Fujii J, Myint T et al. (1996) Reducing sugars trigger oxidative modification and apoptosis in pancreatic $\beta$-cells by provoking oxidative stress through the glycation reaction. Biochem J 320: 855-863

17. El-Deiry WS, Tokino T, Velculescu VE et al. (1993) WAF1, a potential mediator of p53 tumor suppression. Cell 75: 817-825

18. Harper JW, Adami GR, Wei N, Keyomarsi K, Elledge SJ (1993) The p21 Cdk-interacting protein Cip1 is a potent inhibitor of G1 cyclin-dependent kinase. Cell 75: 805-816

19. Noda AY, Ning Y, Venable SF, Pereira-Smith OM, Smith JR (1994) Cloning of senescent cell-derived inhibitors of DNA synthesis using an expression screen. Exp Cell Res 211: 90-98

20. Sherr CJ, Roberts JM (1995) Inhibitors of mammalian G1 cyclin-dependent kinase. Genes Dev 9: 1149-1163

21. Halevy O, Novitch BG, Spicer DB et al. (1995) Correlation of terminal cell cycle arrest of skeletal muscle with induction of $\mathrm{p} 21$ by MyoD. Science 267: 1018-1021

22. Lie M, Lee M-H, Cohen M, Bommakanti M, Freedman LP (1995) Transcriptional activation of Cdk inhibitor in p21 by vitamin D3 leads to the induced differentiation of the myelomonocytic cell line U937. Genes Dev 10: 142-153

23. Qiu X, Forman HJ, Schonthal AH, Cadenas E (1996) Induction of p21 mediated by reactive oxygen species formed during the metabolism of aziridinylbenzoquinones by HCT116 cells. J Biol Chem 271: 31915-31921

24. Yakes FM, Houten BV (1997) Mitochondrial DNA damage is more extensive and persists longer than nuclear DNA damage in human cells following oxidative stress. Proc Natl Acad Sci USA 94: 514-519

25. Ishihara H, Asano T, Tsukuda K et al. (1993) Pancreatic beta cell line MIN6 exhibits characteristics of glucose metabolism and glucose-stimulated insulin secretion similar to those of normal islets. Diabetologia 36: 1139-1145

26. Efrat S, Fusco-DeMane D, Lemberg H, Emran OA, Wang $\mathrm{X}$ (1995) Conditional transformation of a pancreatic $\beta$-cell line derived from transgenic mice expressing a tetracycline-regulated oncogene. Proc Natl Acad USA 92: 3576-3580 